\title{
Correction to: Cytokinin treated microcalli of Phelipanche ramosa: an efficient model for studying haustorium formation in holoparasitic plants
}

\author{
Estelle Billard ${ }^{1} \cdot$ Vincent Goyet $^{1} \cdot$ Philippe Delavault $^{1} \cdot$ Philippe Simier $^{1} \cdot$ Grégory Montiel $^{1}$ (I)
}

Published online: 1 May 2020

C) Springer Nature B.V. 2020

\section{Correction to: \\ Plant Cell, Tissue and Organ Culture (PCTOC) \\ https://doi.org/10.1007/s11240-020-01813-6}

In the initial online publication the caption to Fig. 4 belonged to Fig. 5 and vice versa. The original article has been corrected.
Publisher's Note Springer Nature remains neutral with regard to jurisdictional claims in published maps and institutional affiliations.

The original article can be found online at https://doi.org/10.1007/ s11240-020-01813-6.

Grégory Montiel

gregory.montiel@univ-nantes.fr

Estelle Billard

estelle.billard@univ-nantes.fr

Vincent Goyet

vince.goyet@gmail.com

Philippe Delavault

philippe.delavault@univ-nantes.fr

Philippe Simier

philippe.simier@univ-nantes.fr

1 Laboratoire de Biologie et Pathologie Végétales, Université de Nantes, EA 1157, SFR 4207 QUASAV, UFR Sciences et Techniques, 44322 Nantes, France 